\author{
M. M. Kononenko ${ }^{1}$, \\ orcid.org/0000-0002-1439-1183, \\ O. Ye. Khomenko ${ }^{1}$, \\ orcid.org/0000-0001-7498-8494, \\ I. L. Kovalenko ${ }^{2}$, \\ orcid.org/0000-0002-7747-0911, \\ M.V. Savchenko ${ }^{3}$
}

1 - Dnipro University of Technology, Dnipro, Ukraine, e-mail:kmn211179@gmail.com

2 - Ukrainian State University of Chemical Technology, Dnipro, Ukraine

3 - Ltd IST-FORT, Kharkiv, Ukraine

\title{
CONTROL OF DENSITY AND VELOCITY OF EMULSION EXPLOSIVES DETONATION FOR ORE BREAKING
}

Purpose. Development of a new procedure for calculating the density of emulsion explosives (EE), that will allow determining the detonation velocity along the charging length, depending on the inclination of boreholes during ore breaking.

Methodology. A calculation method for the redistribution of EE density and mass in boreholes at different angles of inclination has been developed by using the well-known laws of hydrostatics. Measurement of the detonation velocity of the EE Ukrainit-PP2B was conducted by using the method of polygon experimental tests. The numerical simulation of changes in the detonation velocity of explosives in boreholes was conducted by using the proposed method and established regularities.

Findings. Methods of calculation of EE density changing along the charging column length under the action of hydrostatic pressure at different angles of inclination of both ascending and descending boreholes have been developed. Based on experimental data, regularities of detonation rate changing from density and charge diameter for EE Ukrainit-PP-2B, varying according to exponential law have been established. The rational initial density of EE Ukrainit-PP-2B has been established for ores breaking by boreholes, which is equal to $800-1000 \mathrm{~kg} / \mathrm{m}^{3}$, at which the detonation rate along the length of the charge column at different angles of inclination of the boreholes is maintained. The obtained results will allow controlling density and detonation velocity during ore breaking.

Originality. The density of EE increases in the formed charging column under the action of hydrostatic pressure: in ascending boreholes - from the face, while in descending boreholes - from the brow.

Practical value. Application of the calculation results of EE density at different inclination angles of boreholes makes it possible to determine in the charge column sections with its critical values more than $1410 \mathrm{~kg} / \mathrm{m}^{3}$, at which a sharp attenuation of the detonation rate begins. Consideration of this phenomenon makes it possible to prevent the occurrence of failures at the explosion of charges in boreholes during ore breaking.

Keywords: drilling-and-blasting operations, emulsion explosives, detonation velocity, charge length, charging cavity

Introduction. The application of emulsion explosives (EE) in mining has its own history. When new explosive chemical compounds were discovered, they were introduced into the mining industry. Increasing safety requirements for drillingand-blasting operations have led to the creation of a number of industrial explosives based on ammonium nitrate, which is used for breaking and grinding hard minerals. After the creation of emulsion explosives (EE) in 1961 [1], as well as the development and improvement of their properties and characteristics, their large-scale implementation began both worldwide in open-cast mining and underground mining [2]. In comparison with trotyl-containing explosives, EE are safer to use, transport and store, and reduce drilling-and-blasting operation expenses [3]. Another benefit of EE is their environmental friendliness $[4,5]$, which is associated with the low man-made impact of the explosion products on the atmosphere $[6,7]$. Thus, to reduce the negative impact of blasting on the environment, all iron-ore enterprises of Ukraine with an open-cast mining method (quarries) switched to EE [8]. The active introduction of blasting technology with the help of domestic production of the "Ukrainit" type, which was started in the quarries in 2003, led to the logical desire of researchers and miners to apply the same technology in underground ore mining enterprises. However, simply replacing of trotyl-containing explosives with EE without changing the blasting technology is unacceptable. The main reasons are the limited size of mine workings, in which it is necessary to place charging equipment, which did not exist at that time. The length of the explosive charge column in underground conditions is 3-4 times longer than in open-cast mining, but with a smaller borehole diameter. And the most important thing is that in underground conditions during blasting

(C) Kononenko M. M., Khomenko O.Ye., Kovalenko I. L., Savchenko M.V., 2021 operations, it is necessary to conduct charging, both in ascending, and descending boreholes which can be located both on parallel, and on radial schemes. These include the development of high-viscosity EE warehouses, retaining primers in boreholes, anti-pyrite additives for EE and much more.

During boreholes charging up to $55 \mathrm{~m}$ long, the hydrostatic pressure intensifies, which increases the density of $\mathrm{EE}$ in the lower part of the charges, by reducing the size of the gas pores. As the density of the EE increases, its sensitivity decreases, and the detonation wave becomes uneven and intermittent until it is completely attenuated. This leads to charge failures, the elimination of which requires large material and technical costs, as well as complex safety measures. Therefore, the examination of changes in the explosive properties and energy characteristics of EE during charging both ascending and descending boreholes in different schemes of ore breaking is an urgent task that will determine the charging parameters and ensure high quality of ore grinding, as well as reduce the prime cost of its breaking.

Literature review. From practical experience, it is wellknown that ore breaking by boreholes is applied in the mining of deposits with a thickness of more than $5 \mathrm{~m}$ regardless of their angle of inclination and the ore massif hardness in subleveland level-and-chamber mining methods, as well as at the sublevel, and level-and-chamber methods with backfilling of the worked-out area. The ore breaking is conducted in a horizontal, vertical free space or in a "clamped" environment by horizontal, inclined, and vertical layers from the chosen design of the mining methods, as well as its features. Parallel, radial, parallel-in-beam, and radial-in-beam schemes of boreholes are applied for that $[9,10]$. The analysis of the application of various schemes of boreholes arrangement for ore breaking in the conditions of iron ore mines of Ukraine is given in Table 1.

The analysis of technological schemes of stoping operations, given in Table 1, as well as design and technical docu- 
mentation, allowed us to establish that the radial scheme of boreholes is applied for iron ore breaking in the mines of Ukraine. Conditions for applying the parallel or parallel-beam schemes for the location of boreholes are very limited due to a number of shortcomings under the radial, which is now the most common one. Basically, these two schemes are applied for vertical compensation space formation, i.e. an end stope. Also, from Table 1, it is apparent that for iron ore breaking, rising radials of boreholes are applied by mines of the Kryvorizkyi basin, while circular radials are used by PJSC "Zaporizkyi Iron Ore Plant". Therefore, research-and-production interest is the examination of changes in the density and mass of charge of filling EE Ukrainit-PP-2B along the length of the charge column at different angles of inclination, both ascending and descending boreholes, ranging from -90 to $+90^{\circ}$.

Horinov S.A., Iliakhin S.V., Maslov I. Yu., Overchenko M. M., Sinitsyn V. O., Fokin V. O., and others were engaged in analytical studies on EE density change in a charging cavity. Based on their results, mathematical models for determining the EE density changing along the length of the vertical charge column with taking into account the hydrostatic pressure have been developed. Thus, Sinitsyn V.O, Menshikov P.V., and Shemenev V. H. proposed to calculate the density of EE, sensitized by gas pores, by the length of the descended borehole charge in 2016 [11]. However, this method does not take into account the change in the value of the hydrostatic pressure at different angles of the EE charge column. According to the results of analytical research by Brahin P.O., Horinov S.O., Maslov I. Yu, Iliakhin S. V., and Overchenko M. M. [12], the method for calculating the density distribution in EE charges, which is sensitized by gas pores, by the height of the charge columns in descending and ascending boreholes, has been proposed in 2015. According to this method, it is established that with descending charges longer than $30 \mathrm{~m}$, their heat shrinkage must be taken into account as well. The benefit of the method is the calculation of the change in the EE density along the length of the charge column for ascending and descending boreholes at different angles. The main shortcoming of the proposed method is a very large array of source data and a complex calculation algorithm. It is established by experimental and calculated data $[13,14]$, that the maximum detonation rate and efficiency of the received explosive have been achieved at a certain density of a charge. Therefore, there is a necessity in examination of the change in the density and velocity of detonation of EE along the length of the charge column at different angles of the charge cavity.
Methods. Development of a new method for calculating the EE density, which allows determining the rate of detonation along the length of the charge depending on the slope of the boreholes during ore breaking. The method of examination of change in the density and rate of EE detonation along the length of the charge column contained the following steps:

- development of a calculation scheme and a new analytical method for calculating the change in density and mass of $\mathrm{EE}$ in the charging cavity at different angles of inclination;

- calculation of the density and mass of EE Ukrainit-PP$2 \mathrm{~B}$ along the length of the charge column at different angles of the charge cavity;

- conducting experiments and results of measurement of detonation velocity of EE Ukrainit-PP-2B in polygon conditions;

- establishment of regularities of change in detonation velocity depending on EE density and charge diameter;

- examination of changes in the rate of detonation along the length of the charge.

The development of a new analytical method for calculating the change in density and mass of EE in the charging cavity at different angles of inclination under the action of hydrostatic pressure was performed by using the well-known laws of hydrostatics and ideal gas. Experimental measurements of the EE detonation velocity have been conducted by the rheostatic method of fixing the detonation velocity, i.e. changing the resistance of the EE charge section length in polygon conditions with the help of the MicroTrap measuring complex.

Results. The development of a new analytical method for calculating the change in density and mass of the EE along the length of the charge column in the charging cavity at different angles of inclination was performed according to the calculation scheme presented in Fig. 1.

It is necessary to set a fixed value of the hydrostatic pressure of the EE column with a length (height) $\Delta l_{i}$ to calculate the EE density at a certain depth along the length of the charge column in the charging cavity.

$$
\Delta P=\rho_{E V R} \cdot g \cdot \Delta l_{i} \cdot 10^{-6},
$$

where $\Delta l_{i}$ is length (height) of the EE layer, which increases the hydrostatic pressure by a fixed value, $\mathrm{m} ; \rho_{E E}$ is density of filling $\mathrm{EE}$ at a fixed hydrostatic pressure, $\mathrm{kg} / \mathrm{m}^{3} ; g$ is the acceleration of free fall equal to $9.81 \mathrm{~m} / / \mathrm{m}^{2}$.

According to the calculation scheme (Fig. 1), the pressure at which the EE layer will be along the length of the charge column with taking into account the angle of inclination of the charging cavity to the horizontal area

Schemes of boreholes arrangement for ore breaking in the conditions of iron ore mines of Ukraine

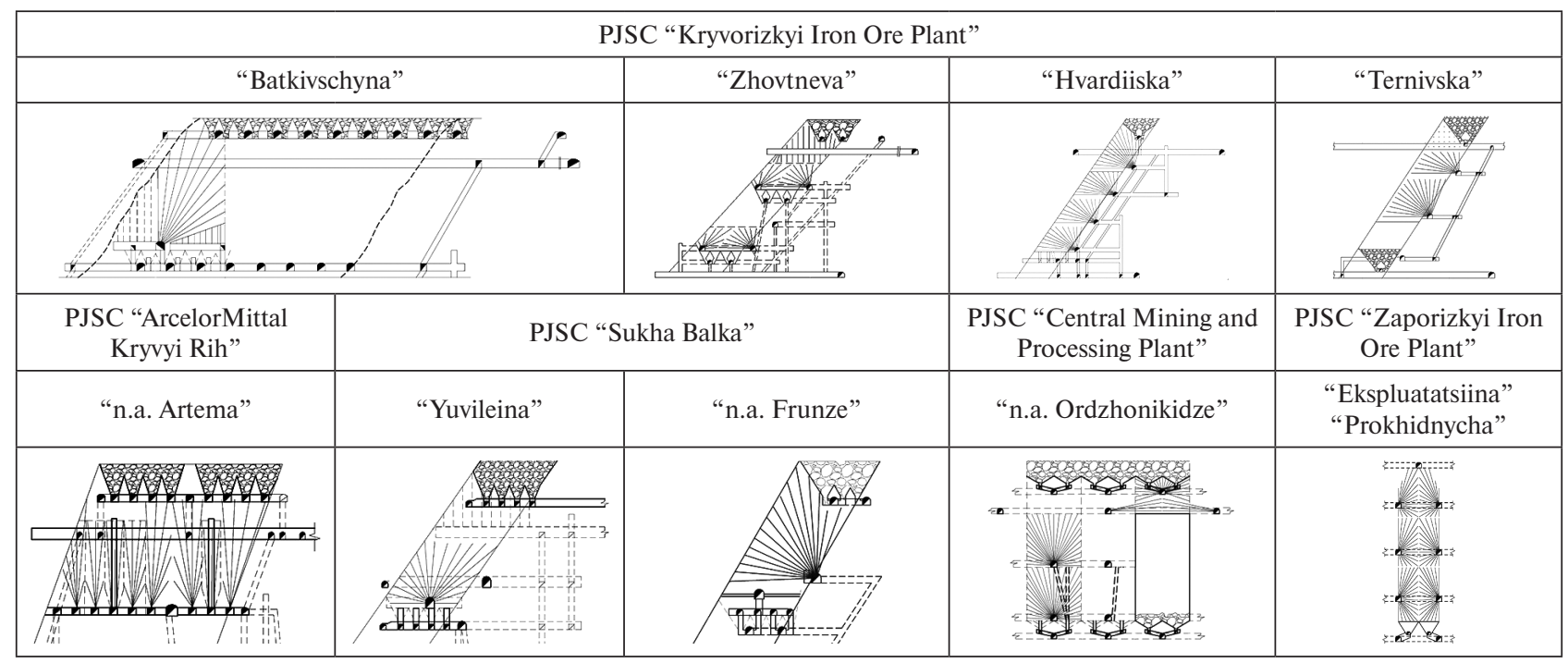



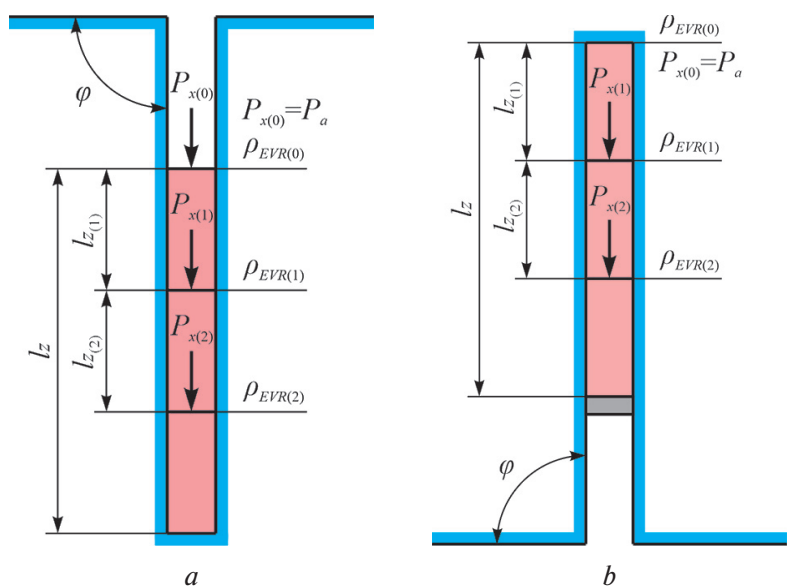

Fig. 1. Calculation scheme for determining the density of EE by the length of the charge column in the descending ( $a$ ) and ascending (b) charging cavities

$$
P_{x(i)}=P_{x(i-1)}+\Delta P \cdot \sin \varphi,
$$

where $\phi$ is the angle of inclination of the charging cavity to the horizontal area, which varies between $0-90^{\circ}$.

As the emulsion consists of immiscible liquids, the maximum density can be calculated from the specific volumes occupied by each of the liquids in the emulsion [11].

At atmospheric pressure $P_{a}=P_{x(0)}$ :

- specific volume of emulsion in explosions

$$
V_{E M}=\frac{1}{\rho_{E M}},
$$

where $\rho_{E M}$ is emulsion density, $\mathrm{kg} / \mathrm{m}^{3} \mathrm{~m}$;

- specific volume of gas inclusions in EE

$$
V_{G(0)}=\frac{1}{\rho_{E V R(0)}}-\frac{1}{\rho_{E M}},
$$

where $\rho_{E V R O)}$ is the density of the filling EE at atmospheric pressure, i.e. the density of the explosive at the output of the charger hose, $\mathrm{kg} / \mathrm{m}^{3}$.

The EE layer with the calculated step $\Delta l_{i}$ along the length of the charge column in the charging cavity is subjected to hydrostatic pressure, while the volume of the emulsion does not change (liquid is not compressed) $V_{E M}=$ const, and the total volume of gas inclusions decreases to $V_{G(i-1)}$. Then, according to Boyle-Marriott's law

$$
V_{G(i)}=\frac{P_{x(i-1)} \cdot V_{G(i-1)}}{P_{x(i)}} .
$$

Density of filling EE in the estimated length $\Delta l_{i}$

$$
\rho_{E V R(i)}=\frac{1}{V_{E M}+V_{G(i)}} .
$$

Average density of EE in the estimated length $\Delta l_{i}$

$$
\rho_{s r E V R(i)}=\frac{\rho_{E V R(i-1)}+\rho_{E V R(i)}}{2} .
$$

According to (1), the length of EE layer, in which the hydrostatic pressure by a fixed value $\Delta P$ will increase

$$
\Delta l_{i}=\frac{\Delta P \cdot 10^{6}}{\rho_{\text {srEVR(i) }} \cdot g} .
$$

The length of the charge column at hydrostatic pressure $P_{x(i)}$

$$
l_{z(i)}=l_{z(i-1)}+\Delta l_{i} .
$$

The mass of EE in a charge of length $l_{i}$ at hydrostatic pressure $P_{x(i)}$

$$
m_{i}=m_{(i-1)}+\frac{\pi \cdot d^{2}}{4} \cdot \Delta l_{i} \cdot \rho_{s r E V R(i)},
$$

where $d$ is diameter of charging cavity, m.

The proposed method is designed to calculate the density and mass of EE, which is sensitized by gas pores, along the length of the charge column at different angles of inclination, both ascending and descending charging cavities. The results of the calculation of the EE density by the new method were compared with the results obtained by Brahin P. O., Horinov S. O., Maslov I. Yu., Iliakhin S. V., Overchenko M. M., Sinitsyn V. O., Menshikov P. V. and Shemenev V.H. in 2015-2016 [11, 12]. The discrepancy of the calculation results for different EE ranges from 1 to $8 \%$, which indicates a high convergence of the obtained results. The value of the EE density consideration allows us to investigate changes in the detonation velocity along the charge length of the filling EE Ukrainit-PP-2B.

Let us calculate the density and mass for filling EE Ukrainit-PP-2B by using the proposed method according to the following initial data: emulsion density $\rho_{E M}=1500 \mathrm{~kg} / \mathrm{m}^{3}$, initial density EE $\rho_{E V R(0)}=950 \mathrm{~kg} / \mathrm{m}^{3}$, atmospheric pressure $P_{a}=0.1013 \mathrm{MPa}$, accepted fixed value of hydrostatic pressure $\Delta P=0.01 \mathrm{MPa}$, the angle of inclination of the charging cavity $\varphi=0,15,30,45,60,75$ and $90^{\circ}$.

As an example, let us consider the change in density and mass along the column length of the filling EE Ukrainit-PP$2 \mathrm{~B}$, which is sensitized by gas pores and placed in the charging cavity with different angles of inclination, represented in Fig. 2.

After further analysis of the results of calculating the change in the density of filling EE Ukrainit-PP-2B at the output of the hose of the charger, equal to 800 and $950 \mathrm{~kg} / \mathrm{m}^{3}$, which is formed by the charge length at the angle of the boreholes from 0 to $90^{\circ}$ at a charge column length up to $55 \mathrm{~m}$, we can conclude that the density of the generated EE charge does not exceed $1410 \mathrm{~kg} / \mathrm{m}^{3}$. This is indicative of a normal detonation rate. With the change in the density of filling EE Ukrainit-PP-2B at the output of the charger hose, which was equal to $1100 \mathrm{~kg} / \mathrm{m}^{3}$, the
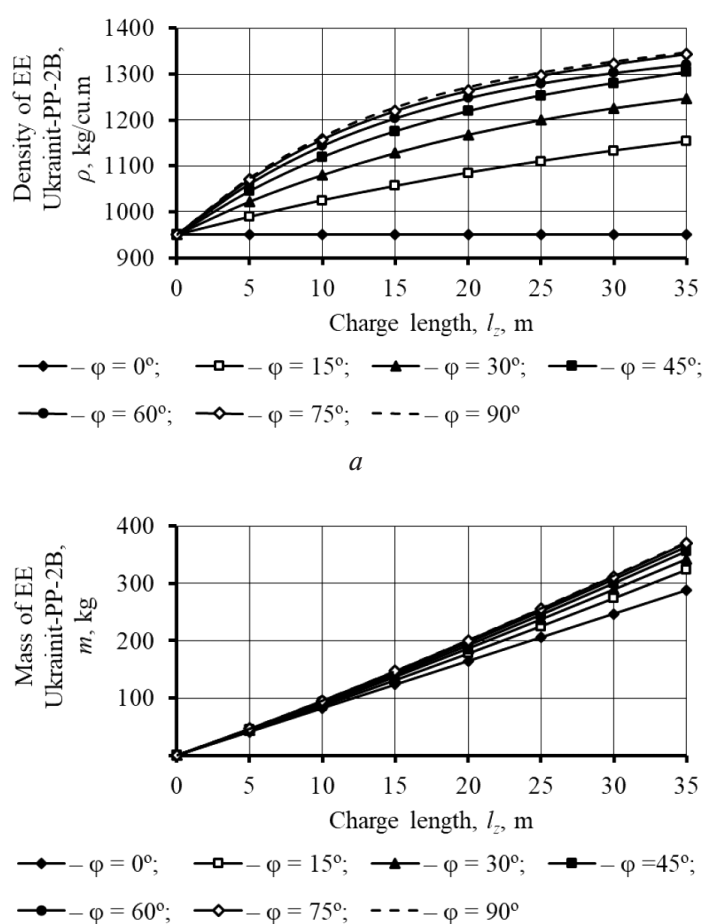

Fig. 2. Diagram of the dependence of the change in density ( $a$ ) and mass $(b)$ of EE Ukrainit-PP- $2 B$ on the length of the charge column on the angle of inclination of the charging cavity at an initial density of $950 \mathrm{~kg} / \mathrm{m}^{3}$ 
density of the generated EE charge at a charge column length of more than $35 \mathrm{~m}$ and angles of $60-90^{\circ}$ begin to exceed the critical density in $1410 \mathrm{~kg} / \mathrm{m}^{3}$. This indicates that the detonation velocity will decrease in this area of the charge until it goes out. Therefore, it is necessary to use the initial density of EE Ukrainit-PP-2B, during charging both ascending and descending boreholes, in the range of $800-1100 \mathrm{~kg} / \mathrm{m}^{3}$ when performing stoping operations related to the ore breaking by radial boreholes, to ensure the design indicators of blasting.

Under the detonation of explosives is understood the process of chemical transformation, which is accompanied by the release of energy and expands through a substance with supersonic velocity, called the detonation wave. It is known, that EE is a mixture of oxidants in the form of a highly concentrated solution of nitrate and non-explosive fuel - petroleum product. Unlike other explosives in the detonation of EE chemical reactions in the front of the detonation wave occur in several stages, and the mechanism, in this case, is determined by the presence of secondary reactions passing the front of the detonation wave and depending on gas diffusion and mixing of individual primary resolving products due to which the detonation process in the EE is conducted in an imperfect mode. This is due to the fact that the time and completeness of the completion of chemical reactions depend on the rate of decomposition and combustion of individual EE particles. And this in turn depends on the uniformity of particles mixing, their size and the presence of hot spots. All these features of the transformation in the detonation wave determine the size of the zone of chemical reactions and establish a direct dependence of the detonation rate of EE on the diameter [15] and the charge density, i.e the density of EE [16, 17].

Measurement of the experimental detonation velocity of filling EE Ukrainit-PP-2B was performed in the test site of the industrial site of PJSC "Promvybukh" (Zaporizhzhia) by using the measuring complex MicroTrap. Plastic pipes with an inner diameter of 30,40 , and $100 \mathrm{~mm}$ and a length of $0.5 \mathrm{~m}$ were applied to simulate the charging cavity, in which a primer and a charge of filling EE Ukrainit-PP-2B were placed. Determination of the detonation velocity was performed at different densities of EE, equal to 800, 900, 1000, 1100, 1150, 1200, 1250, 1300,1350 and $1400 \mathrm{~kg} / \mathrm{m}^{3}$. Thus, as the MicroTrap recorder allows to record up to four measurements simultaneously, 2 series of 3 explosions of samples were performed simultaneously for different diameters and densities of EE Ukrainit-PP-2B. The essential condition for measuring the detonation velocity is the application of reverse initiation by using an electric landing method. Therefore, the primer was placed in the lower part of the tube, and the sensor conductor was placed on the opposite side from the wires of the electric detonator along with the charge. The sensor conductor is short-circuited before placement in the plastic tube. Once placed in the pipe, it is connected to a coaxial cable and connected to the MicroTrap inlets before exploding. The scheme of placement of the conductor-sensor in the test charge and photofixation of the prepared series of charges for the experiment is given in Fig. 3.

As soon as the trigger is functioning, the MicroTrap logger automatically starts collecting measurement data without the presence of staff, which it transmits to independent memory. The saved files from the USB-media were transferred to a personal computer, where with the help of the MicroTrap Software the diagrams of measuring the experimental detonation velocity on samples have been processed and created (Fig. 4).

The results of measuring the detonation velocity of filling EE Ukrainit-PP-2B are given in Table 2.

According to the results of measuring the experimental detonation velocity, given in Table 2, diagrams of dependencies of detonation velocity changing of EE Ukrainit-PP-2B on charge diameter and explosive density are created, which is given in Fig. 5.

After approximating the maximum values, empirical dependencies of the change in the magnitude of the detonation

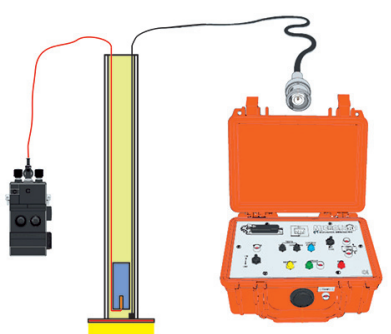

$a$

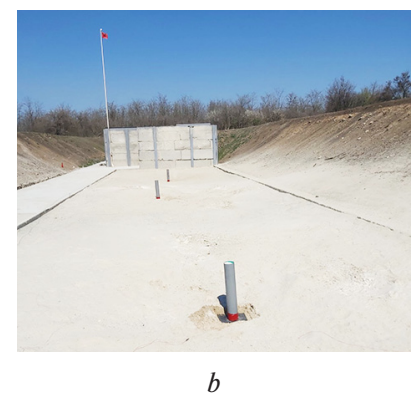

Fig. 3. Scheme of the sensor-conductor arrangement in the test charge (a) and photofixation of the prepared series of charges before the experiment conducting (b)

velocity on the density of EE Ukrainit-PP-2B and the diameter of the charge were obtained. For the determination of detonation velocity of EE Ukrainit-PP-2B at different density and

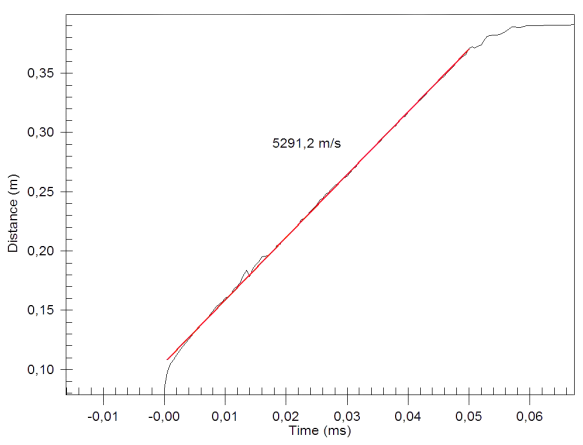

Fig. 4. The result of measuring the detonation velocity of $E E$ Ukrainit- $P P-2 B$ with a density of $1150 \mathrm{~kg} / \mathrm{m}^{3}$ with a charge diameter of $0.1 \mathrm{~m}$, created by MicroTrap Software

Table 2

The results of measuring the experimental detonation velocity EE Ukrainit-PP-2B

\begin{tabular}{|c|c|c|c|}
\hline \multirow{2}{*}{ Density, $\mathrm{kg} / \mathrm{m}^{3}$} & \multicolumn{3}{|c|}{ Charge diameter, $\mathrm{m}$} \\
\cline { 2 - 4 } & 0.03 & 0.04 & 0.10 \\
\hline 850 & 3400 & 3800 & 4400 \\
\hline 900 & 4000 & 4300 & 4600 \\
\hline 1000 & 4200 & 4700 & 5000 \\
\hline 1100 & 4400 & 4800 & 5100 \\
\hline 1150 & 4300 & 4900 & 5300 \\
\hline 1200 & 4300 & 5000 & 5500 \\
\hline 1250 & 4100 & 5100 & 5600 \\
\hline 1300 & 3700 & 4800 & 5450 \\
\hline 1350 & 3200 & 4300 & 5100 \\
\hline 1400 & 2800 & 3600 & 4500 \\
\hline
\end{tabular}


diameter of the charge, the empirical dependences have the following view:

- at density of EE Ukrainit-PP-2B - $800 \leq \rho \leq 1300 \mathrm{~kg} / \mathrm{m}^{3}$

$$
D=(4.8 \cdot \rho+1926) \cdot d^{0.014 \cdot \sqrt[3]{\rho}}
$$

- at density of EE Ukrainit-PP-2B - $1300 \leq \rho \leq 1400 \mathrm{~kg} / \mathrm{m}^{3}$

$$
D=\left(70.6 \rho-0.025 \rho^{2}-38665\right) d^{1.288 \ln (\rho)-8.94} .
$$

The discrepancy between the results of the calculation of the detonation velocity according to formulas $(11,12)$ in comparison with the results given in Table 1 ranges from 1 to $5 \%$, which indicates a high convergence of the results. The consideration of the obtained empirical formulas for calculating the detonation velocity will allow investigating its changes in the charge length of the filling EE Ukrainit-PP-2B.

Scientific-and-practical interest generates the examination of changes in the rate of detonation along the length of the charge at different angles of the charge cavities during ore breaking by radials, both ascending and descending boreholes when the charge length reaches up to $35 \mathrm{~m}$. This is due to the application of different schemes to initiate explosive charges and the location of primers in the charging cavity. Therefore, it is difficult or impossible to make instrumental measurements of the detonation velocity along the charge column. Consideration of the magnitude of the density and detonation velocity has a significant impact on the parameters of the drilling-andblasting operations both during ore mining [18] and drivage of mine workings $[19,20]$.

Let us calculate the change in the rate of detonation along the length of the charge at different angles of inclination of boreholes to establish a rational initial density of EE UkrainitPP-2B for when conducting stoping operations. We used a new method for calculating the magnitude of the change in the density of the EE along the charge length and the obtained formulas $(11,12)$. The calculation of the detonation velocity along the length of the charge column at different angles of the

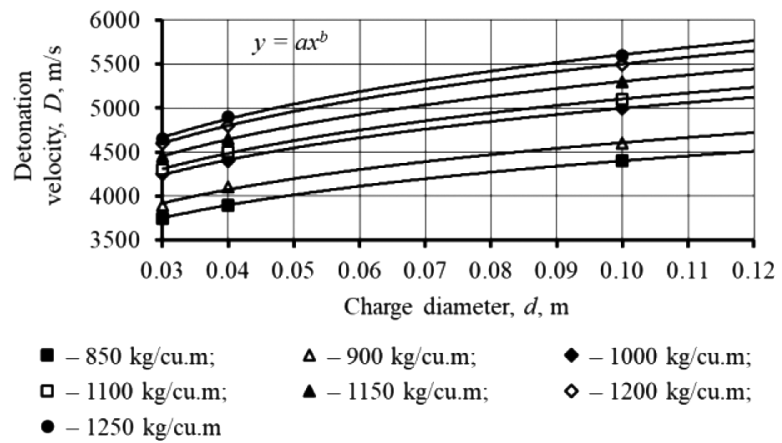

$a$

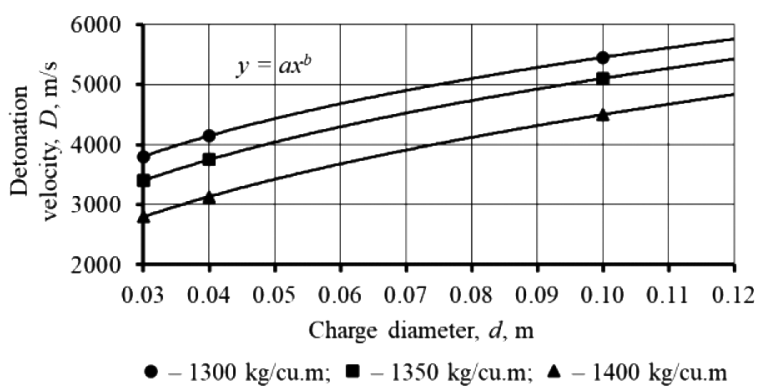

$b$

Fig. 5. Diagram of the dependence of detonation velocity of $E E$ Ukrainit-PP-2B changing on charge diameter and density of emulsion explosive in the amount of 850-1250 (a) and $1300-1400 \mathrm{~kg} / \mathrm{m}^{3}$ boreholes was performed using the following initial data: charge diameter $-0.105 \mathrm{~m}$, charge column length $-35 \mathrm{~m}$, emulsion density $-1500 \mathrm{~kg} / \mathrm{m}^{3}$, initial density of EE UkrainitPP-2B $-800,950$ and $1100 \mathrm{~kg} / \mathrm{m}^{3}$, the value of atmospheric pressure $-0.1013 \mathrm{MPa}$, the accepted fixed value of hydrostatic pressure $-0.01 \mathrm{MPa}$, the angle of inclination of the charging cavity $\varphi=0,15,30,45,60,75$ and $90^{\circ}$.

As an example, let us consider the change in the rate of detonation along the length of the charge at the initial density of EE Ukrainit-PP-2B of $800 \mathrm{~kg} / \mathrm{m}^{3}$ (Fig. 6, $a$ ). As can be seen from the diagram at the angle of inclination of the charging cavity $\varphi=0^{\circ}$, the detonation velocity will be equal to $4300 \mathrm{~m} / \mathrm{s}$, and at the angles of inclination of the charging cavity $0^{\circ}<\varphi \leq 90^{\circ}$, will increase from 4300 to $5690 \mathrm{~m} / \mathrm{s}$. The maximum value of the detonation velocity will be at the maximum length of the charge column, equal to $35 \mathrm{~m}$.

Further examinations of the change in detonation velocity along the charge length at the initial density of EE UkrainitPP-2B of $950 \mathrm{~kg} / \mathrm{m}^{3}$ (Fig. 6, b), revealed that at an angle of inclination of the charge cavity $\varphi=0^{\circ}$ the detonation velocity will be equal to $4750 \mathrm{~m} / \mathrm{s}$. At angles of inclination of the charging cavity $0^{\circ}<\varphi \leq 30^{\circ}$ it will increase from 4750 to $5690 \mathrm{~m} / \mathrm{s}$. At angles of $30^{\circ}<\varphi \leq 45^{\circ}$, the detonation velocity reaches a maximum value of $5700 \mathrm{~m} / \mathrm{s}$ on the length of the charge column up to $30 \mathrm{~m}$ and then decreases to $5550 \mathrm{~m} / \mathrm{s}$ on $35 \mathrm{~m}$ length of the charge column. At angles of inclination of $45^{\circ}<\varphi \leq 75^{\circ}$, at the length of the charge column up to $25 \mathrm{~m}$, the detonation velocity reaches a maximum value of $5750 \mathrm{~m} / \mathrm{s}$, which decreases to $5150 \mathrm{~m} / \mathrm{s}$ at the length of the charge column of $35 \mathrm{~m}$. At angles of inclination of $75^{\circ}<\varphi \leq 90^{\circ}$ at the length of the charge column up to $20 \mathrm{~m}$, the detonation velocity will have a maximum value of $5700 \mathrm{~m} / \mathrm{s}$, which on the length of the charge column from 20 to $35 \mathrm{~m}$ will decrease to $5100 \mathrm{~m} / \mathrm{s}$.
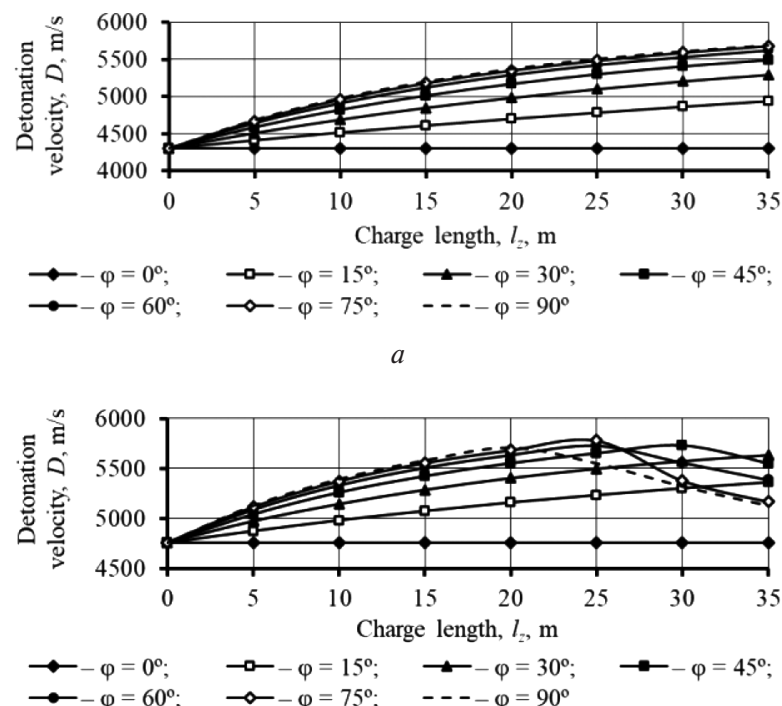

$b$

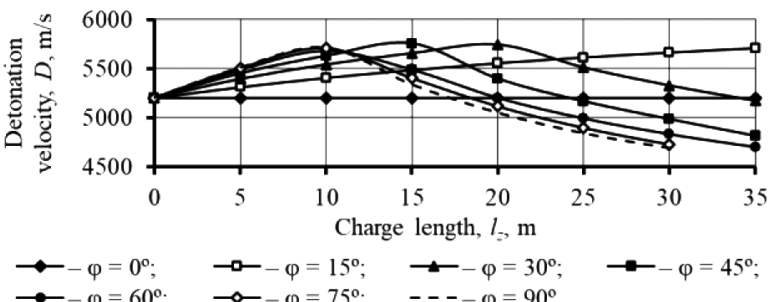

$c$

Fig. 6. Diagram of change in the value of the detonation velocity of EE Ukrainit-PP-2B with an initial density of $800($ a $), 950$ (b) and 1100 (c) $\mathrm{kg} / \mathrm{m}^{3}$ and a charge diameter of $0.105 \mathrm{~m}$ 
At the initial density of EE Ukrainit-PP-2B that is equal to $1100 \mathrm{~kg} / \mathrm{m}^{3}$ (Fig. 6, c), and the angle of inclination of the charging cavity $\varphi=0^{\circ}$, the detonation velocity is equal to $5200 \mathrm{~m} / \mathrm{s}$. For the angles of inclination of the charge cavity $0^{\circ}<\varphi \leq 15^{\circ}$, the detonation velocity along the entire length of the charge column will increase from 5200 to $5700 \mathrm{~m} / \mathrm{s}$. At angles of inclination of $15^{\circ}<\varphi \leq 30^{\circ}$, on the length of the charge column up to $20 \mathrm{~m}$, the detonation velocity acquires the maximum value of $5740 \mathrm{~m} / \mathrm{s}$ and then decreases up to $5170 \mathrm{~m} / \mathrm{s}$ on $35 \mathrm{~m}$ of the charge column length. At angles of inclination of $45^{\circ}<\varphi \leq 60^{\circ}$, on the length of the charge column from 15 to $20 \mathrm{~m}$, the detonation velocity reaches a maximum value of $5500-5700 \mathrm{~m} / \mathrm{s}$, which decreases to $4700 \mathrm{~m} / \mathrm{s}$ on the length of the charge column up to $35 \mathrm{~m}$. At angles of inclination $75^{\circ}<\varphi \leq 90^{\circ}$ and the length of the charge column up to $10 \mathrm{~m}$, the detonation velocity will have a maximum value of $5700 \mathrm{~m} / \mathrm{s}$, which at the length of the charge column up to $30 \mathrm{~m}$ may disappear due to exceeding the critical density.

Thus, according to the results of determining the experimental detonation rate of the emulsion explosive (EE) Ukrainit-PP-2B allowed us:

- to determine the experimental values of the detonation velocity of EE at charge diameters of $0.03,0.04$ and $0.10 \mathrm{~m}$ and the density of the emulsion explosive in the range of $850-1400 \mathrm{~kg} / \mathrm{m}^{3}$ in polygon conditions with the help of the MicroTrap recorder;

- to identify patterns of changes in the detonation velocity of EE Ukrainit-PP-2B depending on the density of the explosive and the diameter of the charge, which vary according to the power law;

- to establish a rational initial density of EE Ukrainit-PP2B for ore breaking by boreholes, which is equal to $800-$ $1000 \mathrm{~kg} / \mathrm{m}^{3}$ at which the normal detonation velocity along the length of the charge column will be maintained up to $35 \mathrm{~m}$ at different angles of charge cavities.

\section{Conclusions.}

1. The analysis of technological schemes of stoping operations conducted at ore mines of Ukraine allowed establishing that at the vast majority for ore breaking, the radial scheme of an arrangement of boreholes, which has become the most widespread today, is applied. However, during the charging of boreholes up to $55 \mathrm{~m}$ long, the hydrostatic pressure intensifies, which leads to increase in the density of EE in the lower part of the charges. This is due to the reduction of gas pore size in the EE. Increasing the density of EE leads to a decrease in its sensitivity, and the detonation wave becomes uneven and intermittent until it completely attenuated. Based on it, a new method has been developed that allows determining the density and mass of EE under the action of hydrostatic pressure at different angles of the boreholes.

2. According to the results of calculating, the change in the density of filling EE Ukrainit-PP-2B with initial values of 800 and $950 \mathrm{~kg} / \mathrm{m}^{3}$ for charge length up to $55 \mathrm{~m}$ at angles of boreholes from 0 to $90^{\circ}$ it was established that the density of the generated charge EE does not exceed the critical value, which is equal to $1410 \mathrm{~kg} / \mathrm{m}^{3}$. With the change in the initial density of filling EE Ukrainit-PP-2B to $1100 \mathrm{~kg} / \mathrm{m}^{3}$, its density at the length of the charge column is more than $35 \mathrm{~m}$, and the angles of inclination of boreholes $60-90^{\circ}$ begin to exceed the value of the critical density. This indicates that the detonation velocity will decrease in this area of the charge until it completely attenuated.

3. Measurements of experimental values of detonation velocity of EE Ukrainit-PP-2B at charge diameters of $0.03,0.04$ and $0.10 \mathrm{~m}$ and emulsion explosive density in the range of 850 $1400 \mathrm{~kg} / \mathrm{m}^{3}$ were conducted in the polygon conditions of PJSC "Promvybukh" (Zaporizhzhia) and made it possible to identify the parameters of the change in the detonation velocity of the EE depending on the density of the explosive and the diameter of the charge, which varies according to the power law.

4. The calculations of changes in the detonation velocity along the length of the charge were performed by using the above mentioned method and adjusted regularities, which allowed to establish a rational initial density of EE Ukrainit-PP-2B for ore breaking, equal to $800-1000 \mathrm{~kg} / \mathrm{m}^{3}$ at which the normal detonation velocity will be maintained along the length of the charge column up to $35 \mathrm{~m}$ at different angles of the boreholes.

Acknowledgments. The authors express strong gratitude to the Doctor of Philosophy in Chemistry, professor, laureate of State prize of Ukraine in science and technology Kuprin V.P. for providing research base and organizational support during polygon experiments.

\section{References.}

1. Lyashenko, V., Vorob'ev, A., Nebohin, V., \& Vorob'ev, K. (2018). Improving the efficiency of blasting operations in mines with the help of emulsion explosives. Mining of Mineral Deposits, 12(1), 95-102. https://doi.org/10.15407/mining12.01.095. 2. Kholodenko, T., Ustimenko, Y., Pidkamenna, L., \& Pavlychenko, A. (2015). Technical, economic and environmental aspects of the use of emulsion explosives by ERA brand in underground and surface mining. New Developments in Mining Engineering, 211-219. https://doi.org/10.1201/b19901-38.

3. Lyashenko, V. I., Golik, V. I., \& Dyatchin, V.Z. (2020). Increasing environmental safety by reducing technogenic load in mining regions. Izvestiya. Ferrous Metallurgy, 63(7), 529-538. https://doi.org/10.17073/0368-0797-2020-7-529-538.

4. Mironova, I., \& Borysovs'ka, O. (2014). Defining the parameters of the atmospheric air for iron ore mines. Progressive Technologies of Coal, Coalbed Methane, and Ores Mining, 333339. https://doi.org/10.1201/b17547-57.

5. Khomenko, O., Kononenko, M., Myronova, I., \& Savchenko, M. (2019). Application of the emulsion explosives in the tunnels construction. E3S Web of Conferences, 123, 01039. https://doi.org/10.1051/e3sconf/201912301039.

6. Myronova, I. (2015). The level of atmospheric pollution around the iron-ore mine. New Developments in Mining Engineering 2015, 193-197. https://doi.org/10.1201/b19901-35.

7. Myronova, I. (2016). Prediction of contamination level of the atmosphere at influence zone of iron-ore mine. Mining of Mineral Deposits, 10(2), 64-71. https://doi.org/10.15407/mining10.02.0064.

8. Gurin, A.A., \& Lyashenko, V. I. (2018). Improvement of the Assessment Methods of the Effect of Mass Emissions in Pits on the Environment. Occupational Safety in Industry, (1), 35-41. https://doi.org/10.24000/0409-2961-2018-1-35-41. 9. Pysmennyi, S., Brovko, D., Shwager, N., Kasatkina, I., Paraniuk, D., \& Serdiuk, O. (2018). Development of complexstructure ore deposits by means of chamber systems under conditions of the Kryvyi Rih iron ore field. Eastern-European Journal of Enterprise Technologies, 5(1(95)), 33-45. https:// doi.org/10.15587/1729-4061.2018.142483.

10. Pysmennyi, S., Fedko, M., Shvaher, N., \& Chukharev, S. (2020). Mining of rich iron ore deposits of complex structure under the conditions of rock pressure development. E3S Web of Conferences, 201, 01022. https://doi.org/10.1051/e3sconf/202020101022.

11. Sinitsyn, V. A., Menshikov, P. V., \& Shemenev, V. G. (2016). Mathematical model of determination of density and aeration length hole charges of emulsion explosives the example Nitronit E-70. Advances in current natural sciences, (8), 205-210.

12. Bragin, P. A., Gorinov, S.A., Maslov, I. Y., Iliakhin, S. V., \& Overchenko, M.N. (2015). On the density distribution in the charge of emulsion explosives sensitized with gas pores. Mining informational and analytical bulletin, (S5-20), 21-37.

13. Kozyrev, S. A., Vlasova, E. A., \& Sokolov, A. V. (2020). Estimation of factual energetics of emulsion explosives by experimental detonation velocity test data. Gornyi Zhurnal, (9), 47-53. https://doi.org/10.17580/gzh.2020.09.06.

14. Gorinov, S.A., \& Kutuzov, B. N. (2012). On the instability of detonation waves of the emulsion explosive with gassensitized cells. Mining informational and analytical bulletin, (4), 302-307. 15. Mertuszka, P., Cenian, B., Kramarczyk, B., \& Pytel, W. (2018). Influence of explosive charge diameter on the detonation velocity based on Emulinit $7 \mathrm{~L}$ and $8 \mathrm{~L}$ bulk emulsion ex- 
plosives. Central European Journal of Energetic Materials, 15(2), 351-363. https://doi.org/10.22211/cejem/78090.

16. Mertuszka, P., Fuławka, K., Pytlik, M., \& Szastok, M. (2019). The influence of temperature on the detonation velocity of selected emulsion explosives. Journal of Energetic Materials, 38(3), 336-347. https://doi.org/10.1080/07370652.2019.1702739. 17. Mertuszka, P., \& Kramarczyk, B. (2018). The impact of time on the detonation capacity of bulk emulsion explosives based on Emulinit 8L. Propellants, Explosives, Pyrotechnics, 43(8), 799-804. https://doi.org/10.1002/prep.201800062.

18. Falshtynskyi, V., Dychkovskyi, R., Khomenko, O., \& Kononenko, M. (2020). On the formation of a mine-based energy resource complex. E3S Web of Conferences, 201, 01020. https://doi.org/10.1051/e3sconf/202020101020.

19. Khomenko, O., Rudakov, D., \& Kononenko, M. (2011). Automation of drill and blast de-sign. Technical And Geoinformational Systems In Mining, 271-275. http://doi.org/10.1201/ b11586-45.

20. Kononenko, M., Khomenko, O., Savchenko, M., \& Kovalenko, I. (2019). Method for calculation of drilling-andblasting operations parameters for emulsion explosives. Mining of Mineral Deposits, 13(3), 22-30. https://doi.org/10.33271/ mining13.03.022.

\section{Керування густиною та швидкістю детонації емульсійних вибухових речовин для відбивання руд}

\section{М. М. Кононенко ${ }^{1}$, О. С. Хоменко ${ }^{1}$, І. Л. Коваленко ${ }^{2}$, М. В. Савченко}

1 - Національний технічний університет «Дніпровська політехніка», м. Дніпро, Україна е-mail: kmn211179@ gmail.com

2 - Український державний хіміко-технологічний університет, м. Дніпро, Україна

3 - ТОВ «ІСТ-ФОРТ», м. Харків, Україна

Мета. Розробити нову методику розрахунку густини емульсійної вибухової речовини (ЕВР), що дозволяє визначити швидкість детонації за довжиною заряду в залежності від нахилу свердловин при відбиванні руд.

Методика. Використовуючи загальновідомі закони гідростатики, розроблена методика розрахунку перерозподілу густини та маси ЕВР у свердловинах за різних кутів нахилу. Методом експериментально-полігонних випробувань проведені вимірювання швидкості детонації ЕВР Україніт-ПП-2Б. За допомогою запропонованої методики та встановлених закономірностей виконано чисельне моделювання зміни швидкості детонації ЕВР у свердловинах.

Результати. Розроблена методика розрахунку зміни густини ЕВР за довжиною колонки заряду під дією гідростатичного тиску за різних кутів нахилу як висхідних, так і низхідних свердловин. На підставі експериментальних даних встановлені закономірності зміни швидкості детонації від густини й діаметру заряду для ЕВР УкраїнітПП-2Б, що змінюються за степеневим законом. Встановлена раціональна початкова густина ЕВР УкраїнітПП-2Б для відбивання руд свердловинами, що становить

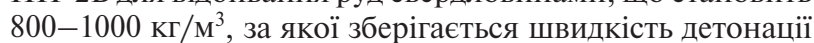
за довжиною колонки заряду за різних кутів нахилу свердловин. Отримані результати дозволять керувати густиною та швидкістю детонації при відбиванні руд.

Наукова новизна. У сформованій колонці заряду під дією гідростатичного тиску густина ЕВР збільшується: у висхідних свердловинах - від вибою, а у низхідних - від устя, що дозволяє за степеневим законом керувати швидкістю детонації через густину вибухівки, кут нахилу й діаметр свердловин.
Практична значимість. Використання результатів розрахунку густини ЕВР за різних кутів нахилу свердловин дозволяє визначити ділянки в колонці заряду з ії критичними значеннями в понад $1410 \mathrm{Kг} / \mathrm{M}^{3}$, за яких розпочинається різке згасання швидкості детонації. Урахування цього явища дозволяє запобігти виникненню відмов при висадженні зарядів у свердловинах при відбиванні руд.

Ключові слова: буропідривні роботи, емульсійні вибухові речовини, швидкість детонації, довжина заряду, зарядна порожнина

\section{Управление плотностью и скоростью детонации эмульсионных взрывчатых веществ для отбойки руд}

\author{
М. Н. Кононенко ${ }^{1}$, О. Е. Хоменко ${ }^{1}$, И. Л. Коваленко ${ }^{2}$, \\ Н. В. Савченко
}

1 - Национальный технический университет «Днепровская политехника», г. Днепр, Украина e-mail: kmn211179@gmail.com

2 - Украинский государственный химико-технологический университет, г. Днепр, Украина

3 - ООО «ИСТ-ФОРТ», г. Харьков, Украина

Цель. Разработать новую методику расчета плотности эмульсионного взрывчатого вещества (ЭВВ), позволяющую определить скорость детонации по длине заряда в зависимости от наклона скважин при отбойке руд.

Методика. С использованием общеизвестных законов гидростатики разработана методика расчета перераспределения плотности и массы ЭВВ в скважинах при разных углах наклона. Методом экспериментально-полигонных испытаний проведены измерения скорости детонации ЭВВ Украинит-ПМ-2Б. С помощью предложенной методики и установленных закономерностей выполнено численное моделирование изменения скорости детонации ЭВВ в скважинах.

Результаты. Разработана методика расчета изменения плотности ЭВВ по длине колонки заряда под действием гидростатического давления при разных углах наклона как восходящих, так и нисходящих скважин. На основании экспериментальных данных установлены закономерности изменения скорости детонации от плотности и диаметра заряда для ЭВВ Украинит-ПМ-2Б, которая изменяется по степенному закону. Установлена рациональная начальная плотность ЭВВ Украинит-ПМ2Б для отбойки руд скважинами, что составляет 800$1000 \mathrm{Kг} / \mathrm{M}^{3}$, при которой сохраняется скорость детонации по длине колонки заряда при разных углах наклона скважин. Полученные результаты позволят управлять плотностью и скоростью детонации при отбойке руд.

Научная новизна. В сформированной колонке заряда под действием гидростатического давления плотность ЭВВ увеличивается: в восходящих скважинах - от забоя, а в нисходящих - от устья, что позволит по степенному закону управлять скоростью детонации через плотность взрывчатки, угол наклона и диаметр скважин.

Практическая значимость. Использование результатов расчета плотности ЭВВ при разных углах наклона скважин позволяет определить в колонке заряда участки с ее критическими значениями более 1410 кг/м ${ }^{3}$, при которых начинается резкое затухание скорости детонации. Учет этого явления позволяет предотвратить возникновение отказов при взрывании зарядов в скважинах при отбойке руд.

Ключевые слова: буровзрывные работы, эмульсионные взрывчатые вещества, скорость детонации, длина заряда, зарядная полость

Recommended for publication by H.A.Symanovych, Doctor of Technical Sciences. The manuscript was submitted 09.11.20. 